\title{
Instrumenty finansowe w ekonomii społecznej wobec kryzysu związanego z pandemią COVID-19
}

\section{Streszczenie}

Sektor ekonomii społecznej to istotny obszar realizacji polityki publicznej w zakresie pomocy społecznej i rynku pracy. Podmioty ekonomii społecznej mają do dyspozycji instrumenty publicznego wsparcia finansowego, w tym zwrotnego, umożliwiające im rozwój i realizację celów gospodarczych i społecznych. W okresie pandemii COVID-19 otrzymały nowe instrumenty wspierające o wyjątkowym charakterze na tle dotychczasowych rozwiązań. Istotnym zagadnieniem jest elastyczność reagowania polityki publicznej oraz umiejętność wspólnego - władzy publicznej wraz ze środowiskiem interesariuszy non-profit - wypracowania i wdrożenia wsparcia, by uchronić ten wrażliwy na kryzysy gospodarcze sektor przed konsekwencjami związanymi z ograniczeniami funkcjonowania podczas pandemii COVID-19. Przedsiębiorstwo społeczne, czy też szerzej przedsiębiorczość społeczna, to $\mathrm{z}$ pewnością jedne $\mathrm{z}$ najbardziej fascynujących innowacji ostatnich dekad, ciągle wymykające się satysfakcjonującemu teoretycznie wyjaśnieniu.

Słowa kluczowe: ekonomia społeczna, finansowe instrumenty zwrotne, COVID-19, integracja społeczna

Kody klasyfikacji JEL: D64, H51, H75, L31, P43

1 Uniwersytet Warszawski, Wydział Stosowanych Nauk Społecznych i Resocjalizacji, r.krenz@uw.edu. pl, https://orcid.org/0000-0001-8352-0164 


\title{
Financial instruments in the social economy in the face of the crisis related to the COVID-19 pandemic
}

\begin{abstract}
The social economy sector is an important area of public policy implementation in social assistance and the labor market. Social economy entities have instruments of public financial support at their disposal, including returnable ones, enabling them to develop and achieve economic and social goals. During the COVID-19 pandemic, they received new support instruments of a unique nature compared to the existing solutions. An important issue is the flexibility of public policy responses and the ability to jointly - the public authority and the non-profit stakeholder community - to develop and implement support to protect this sector, which is sensitive to economic crises resulting from the consequences of operating restrictions during the COVID-19 pandemic. The social enterprise, or more broadly social entrepreneurship, is certainly one of the most fascinating innovations of recent decades, still eluding theoretically satisfactory explanation.
\end{abstract}

Keywords: social economy, financial feedback instruments, COVID-19, social inclusion JEL Classification Codes: D64, H51, H75, L31, P43

Ekonomia społeczna to nie tylko trwały, ale także stale rozwijający sie sektor współczesnej gospodarki, różny od sektora rynkowego i publicznego. Autorzy przygotowywanego cyklicznie przez International Centre of Research and Information on the Public, Social and Cooperative Economy (CIRIEC) na zlecenie Europejskiego Komitetu Ekonomiczno-Społecznego raportu konkludują, że nowa gospodarka staje się coraz bardziej niezbędna w dobie globalizacji gospodarki i społeczeństwa. Podkreślają wyzwania i rolę, jaką gospodarka społeczna może odegrać w społeczeństwie dobrobytu (Monzón, Chaves, 2012: 55).

Dzięki swej odmienności - łączeniu tego, co klasyczna (liberalna) ekonomia rozdziela: (1) działalności ekonomicznej ukierunkowanej na zysk oraz (2) realizacji celów stricte społecznych (por. Rymsza, 2011b: 22; Sałustowicz, 2007) - z sukcesem wkracza, i wkraczać będzie, w te obszary, w których państwo i rynek okazują się zawodne (Bouchard, 2009). Fakt ten nie tylko wyjaśnia rozwój sektora ekonomii społecznej, ale wskazuje także na źródła jego obecnej i przyszłej dynamiki.

Polska ma bogate tradycje ekonomii społecznej, które współkształtowały kontynentalny model ekonomii społecznej (opis modelu - por. Pacut, 2012). W okresie zaborów na ziemiach polskich rozwijał się ruch spółdzielczy, zakładano liczne kasy pożyczkowe oraz podejmowano inne przedsięwzięcia ekonomiczne o charakterze 
wzajemnościowym. W II Rzeczypospolitej spółdzielczość, kasy kredytowe i towarzystwa ubezpieczeń wzajemnych stały się znaczącymi elementami krajowej gospodarki (Piechowski, 2007). Paradoksalnie lata 90. XX w. - dekada transformacji ustrojowej - były okresem niekorzystnym dla ekonomii społecznej, którą potraktowano wówczas jako relikt socjalizmu.

Akcesja Polski do Unii Europejskiej (UE) dała rozwojowi ekonomii społecznej nowy impuls do rozwoju. Na pierwszy plan polityka unijna wybijała jej funkcje prozatrudnieniową, zwłaszcza dotyczącą osób marginalizowanych na rynku pracy (por. Kelly, 2003: 34). Stąd szczególne zainteresowanie rozwojem przedsiębiorstw społecznych typu WISE (work integration social enterprises; przedsiębiorstwa integracji społecznej przez pracę; por. Kaźmierczak, 2014), w tym spółdzielni socjalnych, czego wyrazem było miejsce tej problematyki w Inicjatywie Wspólnotowej EQUAL (por. MGPiPS, 2004), a następnie w Programie Operacyjnym Kapitał Ludzki (por. MRR, 2007). Stopniowo jednak rosła świadomość znaczenia przedsiębiorczości społecznej dla rozwoju lokalnego, zwłaszcza terenów ekonomicznie niedoinwestowanych (Kaźmierczak, 2008; Leś, Ołdak, 2007) i w systemie usług społecznych. Przedsiębiorstwo społeczne zaczęto łączyć z szeroką kategorią usług użyteczności publicznej (services of general interest), w szczególności usługami społecznymi (social services of general interest) oraz usługami kulturalnymi (cultural services of general interest). Dla tej ewolucji znaczące były zarówno doświadczenia praktyczne (w tym krajowe), jak i regulacje europejskie oraz zalecenia co do kierunków rozwoju ekonomii społecznej w Polsce (por. OECD, 2009). Ewolucja ta została w pełni uwzględniona w Krajowym Programie Rozwoju Ekonomii Społecznej (KPRES). Zgodnie z przyjętą na jego użytek definicją ekonomia społeczna to „sfera aktywności obywatelskiej, która poprzez działalność ekonomiczną i działalność pożytku publicznego służy: integracji zawodowej i społecznej osób zagrożonych marginalizacją społeczną, tworzeniu miejsc pracy, świadczeniu usług społecznych użyteczności publicznej (na rzecz interesu ogólnego) oraz rozwojowi lokalnemu“ (MRPiPS, 2019: 12) lub szerzej można zakreślić, że ekonomia społeczna jest sferą życia społeczno-gospodarczego, która pozostaje na pograniczu sektora przedsiębiorczości oraz sektora organizacji pozarządowych niedziałających w celu maksymalizacji zysku. Solidarnościowy wymiar ekonomii społecznej (ekonomia solidarna) realizowany jest przez te podmioty ekonomii społecznej, w szczególności przedsiębiorstwa społeczne, które w ramach swojej działalności przyjmują funkcje tworzenia miejsc pracy w celu aktywizacji oraz reintegracji zawodowej i społecznej osób zagrożonych wykluczeniem społecznym, świadczenia usług społecznych użyteczności publicznej oraz realizacji zadań publicznych w zakresie rozwoju lokalnego (por. MRiPS, 2021). Pojęcia „przedsiębiorstwo ekonomii społecznej“ (PES) oraz „przedsiębiorstwo społeczne“ (PS) używane są 
w sposób zdefiniowany w Krajowym Programie Rozwoju Ekonomii Społecznej do 2023 r. Ekonomia solidarności społecznej (MRPiPS, 2019)².

W centrum problematyki współczesnej ekonomii społecznej leży kwestia przedsiębiorstwa społecznego - nowego rodzaju podmiotu, który w sposób funkcjonalny łączy aktywność ekonomiczną na rynku z realizacją misji społecznej (por. Alter, 2008; Laville, Nyssens, 2008). Przedsiębiorstwo społeczne prowadząc w możliwie racjonalny ekonomicznie sposób działalność gospodarczą, nie dąży do maksymalizacji zysku (jako finansowego rezultatu prowadzonej działalności), ale do maksymalizacji społecznej wartości dodanej. Od w pełni komercyjnych firm różni je stosowanie udemokratycznionych procedur zarządzania (gdzie siła głosu nie musi być wprost proporcjonalna do wielkości posiadanych udziałów) oraz uspołeczniony sposób nadzoru i zagospodarowania nadwyżki finansowej. Przedsiębiorstwa społeczne mają także możliwość korzystania $\mathrm{z}$ dotacji publicznych, ulg i przywilejów finansowych jako form zachęty do realizacji misji społecznej (np. oferowania pracy osobom słabszym, mniej wydajnym ekonomicznie), a tym samym rezygnacji z dążenia do maksymalizacji zysku. Te m.in. cechy przedsiębiorstw społecznych przesądzają o ich tzw. hybrydowej naturze (por. Billis, 2010). Dzięki niej mogą one łączyć funkcje trudne do pogodzenia, np. prozatrudnieniową z usługodawczą, co charakteryzuje sporą część polskich spółdzielni socjalnych. Takie rozwiązanie jest wzorowane na doświadczeniach włoskich, gdzie najpierw rozróżniono dwa typy spółdzielni socjalnych - usługodawcze (typ A) i prozatrudnieniowe (typ B), a następnie rozwijano spółdzielnie hybrydowe typu A/B (por. Loss, 2005; Lachowicz, 2008). Hybrydowość spółdzielni socjalnych przejawia się także w tym, że łączą one cechy spółdzielni i organizacji pozarządowej (por. Izdebski, 2006). Kluczowa jest też więziotwórcza funkcja przedsiębiorstw społecznych, w których ich unikatowość łączy się ze zdolnością do wzmacniania zarówno więzi poziomych, jak i opartych na wzajemności z integracją wertykalną (więzi pionowe), polegającą na inkluzji osób wykluczonych i marginalizowanych (por. Rymsza, 2011a).

W Polsce nie ma legalnej (prawnej) definicji przedsiębiorstwa społecznego (por. Schimanek, 2012), co odpowiada anglosaskiej tradycji ekonomii społecznej (por. Izdebski, 2012). Przedsiębiorstwa społeczne funkcjonują w następujących formułach prawno-instytucjonalnych (por. Rymsza, 2014: 364, rys. 12.1): (1) wspomnianych

2 Dokument stanowiący rozwinięcie i doprecyzowanie działań wynikających z Krajowego Programu Rozwoju Ekonomii Społecznej, przyjętego uchwałą nr 164 Rady Ministrów z dnia 12 sierpnia 2014 r. (M.P. poz. 811). Program rozwoju w rozumieniu art. 15 ust. 4 pkt 2 ustawy z dnia 6 grudnia 2006 r. o zasadach prowadzenia polityki rozwoju (Dz.U. 2018, poz. 1307 z późn. zm.), dokument o charakterze operacyjno-wdrożeniowym, ustanowiony w celu realizacji średniookresowej strategii rozwoju kraju - Strategii na rzecz Odpowiedzialnego Rozwoju, przyjętej uchwałą nr 8 Rady Ministrów z dnia 14 lutego 2017 r., oraz innych strategii rozwoju. 
już spółdzielni socjalnych, (2) jako strukturalnie wyodrębniona działalność gospodarcza organizacji pozarządowych i podmiotów z nimi zrównanych (np. kościelne podmioty trzeciego sektora), (3) jako organizacje wzajemnościowe prowadzące aktywność ekonomiczną (np. towarzystwa ubezpieczeń wzajemnych) oraz (4) jako spółki non-profit (formułą wykorzystywaną stosunkowo najrzadziej). Działając w obrębie ekonomii społecznej, wykształciły się ich trzy podstawowe typy: przedsiębiorstwa integracji społecznej przez pracę, przedsiębiorstwa społeczne zorientowane na rozwój lokalny oraz przedsiębiorstwa świadczące usługi społeczne, określane też jako usługi użyteczności publicznej. Badania dowiodły, że inne są warunki ich trwania i rozwoju i przed innymi rodzajami wyzwaniami stoją (Kaźmierczak, 2013). Ekonomia społeczna wymaga zatem innych form wsparcia w tym zróżnicowanych instrumentów finansowych.

\section{Instrumenty finansowe w obszarze ekonomii społecznej}

Podmioty ekonomii społecznej w niewielkim stopniu korzystają ze zwrotnych instrumentów finansowania. Analizę przyczyn tego stanu rzeczy zawiera opracowanie Ocena ex-ante instrumentów finansowych w zakresie wsparcia podmiotów ekonomii społecznej i osób młodych Ministerstwa Infrastruktury i Rozwoju (Andrzejewska et al., 2014). Wprawdzie raport został opublikowany w 2014 r., lecz wydaje się, że wiele prezentowanych w nim ustaleń nie straciło na aktualności. Celem opracowania była m.in. ocena zapotrzebowania na instrumenty zwrotne w odniesieniu do przedsiębiorstw społecznych oraz sformułowanie propozycji instrumentów zwrotnych, możliwych do wdrażania w ramach Programu Operacyjnego Wiedza Edukacja Rozwój 2014-2020. Ewaluacja została przeprowadzona na podstawie różnych metod i technik badawczych (analizy danych zastanych, badań ilościowych i jakościowych). Jak wynika z raportu (Andrzejewska et al., 2014), prawie 58\% przedsiębiorstw społecznych deklarowało poniesienie wydatków rozwojowych, lecz zaledwie jeden na 10 podmiotów z tej grupy sfinansował je z kredytu lub pożyczki.

Wśród najważniejszych powodów niezrealizowania wydatków na rozwój badane podmioty ekonomii społecznej wskazywały: brak własnych pieniędzy na inwestycje, brak dostępu do dotacji, brak dostępu do kredytu lub pożyczki, brak dostępu do poręczenia, brak wiedzy o tym, jak zaplanować zwrot $\mathrm{z}$ inwestycji, jak również niestabilną sytuację ekonomiczną podmiotu. Z kolei do najczęściej wymienianych przyczyn nieubiegania się o skorzystanie ze zwrotnych instrumentów finansowych (pożyczek lub kredytów) należą:

- preferowanie dotacji przez PES (71\%),

- obawa przed podjęciem ryzyka (65\%), 
- brak wymaganych zabezpieczeń (49\%),

- nieposiadanie wystarczających przychodów własnych (43\%),

- niespełnianie kryteriów wymaganych przez instytucje finansowe (36\%),

- nieplanowanie inwestycji (34\%),

- uciążliwe obciążenia biurokratyczne (32\%),

- brak znajomości dostępnej oferty (22\%),

- wysoki nakład pracy własnej konieczny do uzyskania finansowania (17\%).

We wspomnianym opracowaniu sformułowanych zostało kilka istotnych rekomendacji na potrzeby wprowadzania instrumentów o charakterze zwrotnym do systemu wsparcia sektora ekonomii społecznej. Chodzi o zbudowanie wielowymiarowego i zarazem spójnego logicznie systemu wsparcia, łączącego różne instrumenty i umożliwiającego elastyczne konstruowanie różnych montaży finansowych. Niezmiernie istotne jest uwzględnienie instrumentów o charakterze gwarancyjnym, które mogą być istotnym wzmocnieniem systemów pożyczkowych lub kredytowych. Wiele istotnych informacji na ten temat zawiera raport Ocena ex ante ryzyka dla zastosowania instrumentów finansowych o charakterze gwarancyjnym oferowanych podmiotom ekonomii społecznej w ramach PO WER (Programu Operacyjnego Wiedza Edukacja Rozwój) (Gajewski et al., 2015). Niespełna co czwarty ankietowany PES podjął próbę uzyskania kredytu bankowego w okresie trzech lat od daty realizacji pomiaru, większość z nich nie podejmuje takich działań. Im większe podmioty, tym częściej ubiegały się o kredyt bankowy. Rozbudowany zestaw informacji na ten temat można odnaleźć w raporcie końcowym do badania Ewaluacja systemu pożyczkowego (Grabowska et al., 2017). Wypracowane zostały rekomendacje dotyczące tworzenia oferty pożyczkowej dla podmiotów ekonomii społecznej, służące planowaniu i optymalizacji dalszych działań w ramach EFS w tym obszarze (m.in. na podstawie panelu ekspertów, w którym wzięli udział przedstawiciele administracji publicznej oraz sektora ekonomii społecznej).

W okresie od marca 2013 r. do grudnia 2016 r. udzielonych zostało 500 pożyczek, z których skorzystało 400 podmiotów. Pożyczki opiewały na łączną kwotę $38,9 \mathrm{mln}$ PLN, a prawie $90 \% \mathrm{z}$ nich zostało udzielonych na maksymalny dopuszczalny okres pięciu lat. Średnie oprocentowanie pożyczki wyniosło $0,77 \%$. Ponad połowa pożyczek została udzielona spółdzielniom socjalnym, mimo że ich udział w zbiorowości podmiotów ekonomii społecznej wynosi nieco ponad $1 \%$. Wiąże się to z faktem, że oferta pożyczkowa skierowana była do PES prowadzących działalność gospodarczą, która - niejako z definicji - jest podejmowana przez spółdzielnie socjalne. Dla porównania - przychody z działalności gospodarczej osiąga zaledwie kilka procent organizacji pozarządowych. Według danych zamieszczonych w raporcie (Grabowska et al., 2017: 53) pomoc zwrotna trafiła przede wszystkim do podmiotów młodych 
(60\% z nich powstało między 2010 a 2015 r.), co wiąże się z faktem, że w większości ze wsparcia skorzystały spółdzielnie socjalne, które funkcjonują w polskim systemie od roku 2004, a w latach 2010-2016 ich liczba wzrosła sześciokrotnie. Co czwarty pożyczkobiorca działał w obszarze gastronomii - branża ta była domeną spółdzielni socjalnych, wśród których była reprezentowana przez ponad $80 \%$ podmiotów. Z kolei fundacje i stowarzyszenia najczęściej prowadziły działalność w obszarze kultury (17\%), turystyki (15\%) oraz edukacji (14\%). Jak wynika z raportu (Grabowska et al., 2017: 55), wielkość zatrudnienia w spółdzielniach socjalnych, które otrzymały pożyczkę, była zbliżona do średniej dla zbiorowości tego rodzaju podmiotów. Natomiast jeśli chodzi o fundacje i stowarzyszenia, zauważono, iż z pożyczek skorzystały relatywnie duże podmioty, co wynika z faktu, że działalność gospodarczą najczęściej prowadzą większe organizacje „trzeciego sektora”. W dokumencie możemy odnaleźć informacje, że korzystające z pożyczek spółdzielnie socjalne częściej zatrudniały osoby niepełnosprawne ( $38 \%$ w tej grupie podmiotów) niż fundacje i stowarzyszenia (23\%), co również nie jest zaskoczeniem, ponieważ niepełnosprawni są jedną z grup najczęściej zatrudnianych przez spółdzielnie socjalne. Z prezentowanego $\mathrm{w}$ raporcie (Grabowska et al., 2017: 58) rozkładu odpowiedzi na pytanie o wysokość przychodów w roku poprzedzającym złożenie wniosku o przyznanie pożyczki wynika, że 38,8\% podmiotów uzyskało przychód nie większy niż 100 tys. PLN, 29,6\% - od 100 tys. do $1 \mathrm{mln}$ PLN, natomiast 18,8\% - powyżej $1 \mathrm{mln}$ PLN. W grupie podmiotów o najwyższych przychodach zdecydowanie dominowały organizacje pozarządowe, zaś wśród pożyczkobiorców o najniższych przychodach przeważały spółdzielnie socjalne. Z analizy dowiadujemy się, że o pożyczkę ubiegały się podmioty o ponadprzeciętnie dobrej kondycji finansowej na tle reprezentowanego sektora, co wydaje się dość oczywistą konstatacją.

Bariery korzystania $\mathrm{z}$ finansowania zwrotnego przez podmioty ekonomii społecznej można podzielić na dwie grupy: wewnętrzne i zewnętrzne. „Wewnętrzne bariery wynikają głównie ze skali działalności (niewielkie, nieregularne przychody) i ostrożnościowej strategii działania w zakresie finansowania zewnętrznego (strategia przetrwania). Bariery zewnętrzne wynikają z braku oferty pożyczkowej dla PES-ów na rynku komercyjnym spowodowanego niechęcią banków do finansowania tego typu podmiotów (ze względu na koszty obsługi przy niewielkim zysku i podwyższonym ryzyku) i dość wysokich wymagań prawa bankowego co do standingu finansowego kredytobiorcy, których na ogół PES-y nie spełniają" (Grabowska et al., 2017: 5).

Bardzo istotnym elementem ocenianego systemu były usługi doradcze dla pożyczkobiorców. Skorzystanie z tej możliwości nie było obligatoryjne, lecz 60\% klientów programu dokonało takiego wyboru. Przeciętny czas poświęcony przez doradców 
na wsparcie jednego podmiotu wynosił 10 godz. Dzięki ich pomocy merytorycznej wzrósł poziom poczucia bezpieczeństwa pożyczkobiorców, dla których korzystanie z tego rodzaju narzędzi najczęściej było nowym doświadczeniem i w ich ocenie wiązało się z koniecznością podjęcia ryzyka. Usługi doradcze najczęściej obejmowały zagadnienia związane z rozliczeniem pożyczki (30\%), informacją i promocją (20\%), księgowością (13\%) oraz zarządzaniem zasobami ludzkimi (10\%). Przedstawiciele podmiotów, które skorzystały z doradztwa, pozytywnie ocenili tę formę wsparcia, a zwłaszcza przygotowanie merytoryczne doradców (87\%), lokalizację miejsca świadczenia usługi (81\%), poruszaną tematykę (71\%) oraz liczbę dostępnych godzin pracy doradcy (73\%). Jednocześnie $78 \%$ respondentów korzystających z doradztwa zadeklarowało, że usługa ta pomogła im w przeprowadzeniu inwestycji i skutecznym wykorzystaniu pożyczonych środków (odmienną opinię wyraziło $14 \%$ badanych z tej grupy).

Jak pokazują wyniki badań ewaluacyjnych (Grabowska et al., 2017), 47\% pożyczkobiorców Krajowego Funduszu Przedsiębiorczości Społecznej przynajmniej jedną ratę zapłaciło z opóźnieniem, natomiast w przypadku jednej piątej umów wystąpiły przynajmniej trzymiesięczne opóźnienia w spłacie rat. Spośród 500 umów 79 postawionych zostało w stan windykacji, a 48 z nich - w stan natychmiastowej wymagalności. Do zdiagnozowanych przyczyn problemów ze spłatą zobowiązań należą: niższe od oczekiwanych przychody, sezonowy charakter działalności, wypadki losowe, niskie kompetencje do prowadzenia działalności gospodarczej, jak również nieporozumienia między osobami prowadzącymi organizację.

Jako pozytywne efekty zrealizowanych działań przedstawiciele badanych PES-ów najczęściej wskazywali: wzrost przychodów (86\%), zwiększenie sumy bilansowej (69\%), wzrost poziomu zatrudnienia (63\%). Ponadto respondenci różnią się pod względem opinii, czy system pożyczkowy w większym stopniu przyczynił się do wystąpienia pozytywnych efektów społecznych (23\%), czy ekonomicznych (25\%). Istotnym kryterium ewaluacyjnym jest również trwałość uzyskanych efektów. Jak wynika z raportu (por. Grabowska et al., 2017: 53), możliwości sformułowania tego rodzaju oceny były dość ograniczone z uwagi na relatywnie krótki czas, jaki upłynął od zakończenia działań projektowych. Podczas badania ilościowego prawie 64\% ankietowanych podmiotów zadeklarowało utrzymanie wszystkich miejsc pracy, powstałych dzięki pożyczce, natomiast $26 \%$ badanych organizacji utrzymało część z nich. Jednocześnie $98 \%$ wspomnianych podmiotów kontynuowało dotychczasową działalność gospodarczą. Pożyczka okazała się koniecznym warunkiem realizacji zadań - tylko 1,5\% respondentów uznało, że działania te mogłyby zostać wykonane nawet bez udziału w programie. Dogodne instrumenty pożyczkowe w ekonomii społecznej stają się niezbędnym instrumentem wsparcia, którego podmioty te nie mogą 
otrzymać na rynku (luka finansowa). Z analiz płynie również wniosek, że korzystanie z systemu pożyczkowego miało pozytywny efekt w obszarze edukacji ekonomicznej, ponieważ przyczyniło się do zmiany postaw pożyczkobiorców na bardziej rynkowe. Podjęcie zobowiązań finansowych wpłynęło na upowszechnienie profesjonalizmu i planowania strategicznego w podmiotach ekonomii społecznej.

Atrakcyjność instrumentu finansowego zwrotnego jest na pewno mniejsza niż atrakcyjność dotacji. Dlatego łączenie form zwrotnych i bezzwrotnych wsparcia pozwala wywoływać określone synergie, wynikające z „połączenia” zalet obu tych form (zob. Bilal, Krätke, 2013). Niestety w rzeczywistości ukształtowanej architektury form wsparcia w okresie programowania 2014-2020 warunki łączenia instrumentów okazały się stosunkowo restrykcyjne ze względu na konieczność rozdzielania kosztów kwalifikowalnych finansowania udostępnianego za pomocą różnych form wsparcia oraz konieczność przestrzegania regulacji w sprawie pomocy publicznej z instrumentami zwrotnymi, bezzwrotnymi i mieszanymi programów Polityki Spójności (PO, RPO) 2014-2020 oraz wybranych programów krajowych.

W obecnym okresie programowania kontynuacją są pożyczki udzielane ze środków działania 2.9 „Rozwój ekonomii społecznej” Programu Operacyjnego Wiedza Edukacja Rozwój (PO WER). Do końca lutego 2020 r. udzielono 764 pożyczki o wartości ok. 85,8 mln PLN (dane Banku Gospodarstwa Krajowego), co oznacza, że postęp wdrażania instrumentu okazał się co najmniej zgodny z założeniami. Raport Badanie potrzeb finansowych i pozafinansowych w sektorze ekonomii społecznej oraz usług społecznych i zdrowotnych (Gajewski et al., 2020) przygotowany w związku z programowaniem wsparcia dla PES w ramach perspektywy finansowej 2021-2027 (EFS+), opisuje kondycję finansową podmiotów ekonomii społecznej. Danych dostarczają wyniki ostatnich badań Głównego Urzędu Statystycznego zaprezentowane w publikacjach Ministerstwa Rodziny, Pracy i Polityki Społecznej. Badania te były przeprowadzone w 2018 r. i dostarczają danych za 2017 r. Pierwsze z badań dotyczyło podmiotów ekonomii społecznej i objęło: stowarzyszenia i podobne organizacje, fundacje, społeczne podmioty wyznaniowe oraz samorząd gospodarczy. Przychody tak zdefiniowanej grupy podmiotów wyniosły 27,7 mld PLN. Ponad połowę tej kwoty stanowiły przychody stowarzyszeń, ok. 36\% to przychody fundacji, a $10 \%$ stanowiły przychody społecznych podmiotów wyznaniowych. Przychody organizacji non-profit są bardzo zróżnicowane wewnętrznie. Mediana przychodów wyniosła 19,9 tys. PLN. Oznacza to, że połowa tych podmiotów osiągnęła przychody nie wyższe niż ta wartość. Natomiast średnia wartość przychodów wyniosła 301 tys. PLN. Wartości te były silnie zróżnicowane ze względu na typ organizacji. Niższe od średniej przychody osiągały stowarzyszenia, a wyższe - fundacje, organizacje pożytku publicznego oraz społeczne podmioty wyznaniowe. W 2017 r. pożyczki lub kredyty 
zaciągnęło 1,3 tys., czyli 1,4\% wszystkich organizacji non-profit. Na tym tle wyróżniają się organizacje korzystające z usługi Ośrodków Wsparcia Ekonomii Społecznej (OWES), wśród których z pożyczek lub kredytów korzystało 5,7\% organizacji.

\section{Instrumenty finansowe w obszarze ekonomii społecznej w okresie pandemii COVID-19}

Pierwsze sondażowe reakcje na ograniczenia związane z COVID-19 wskazywały na znaczną skalę kryzysu w sektorze ekonomii społecznej. Badania podjęte przez OWES informowały, że w zasadzie cały sektor doświadcza znacznych trudności w zachowaniu bieżącej działalności gospodarczej, a tym samym efektów społecznych, tj. zatrudnienia osób wykluczonych, i przewiduje konieczność ograniczenia zatrudnienia, ryzyko utraty płynności, a aż $27 \%$ przewidywało możliwość likwidacji. Duża część przedsiębiorstw społecznych nie dysponuje rezerwami finansowymi lub ma niewielkie możliwości w tym zakresie. Wyniki badania przeprowadzonego w dniach 19-20 marca 2020 r. w Wielkopolsce na próbie 22 przedsiębiorstw - bezpośrednio po wprowadzeniu ograniczeń związanych z pandemią - potwierdziły hipotezę o dramatycznych prognozach i nastrojach wśród przedsiębiorców społecznych (por. OWES, 2020). Zgodnie z tymi badaniami aż 95\% badanych PS wskazywało, że spodziewa się doświadczać bądź już doświadcza negatywnych skutków epidemii. Aż 86\% badanych podmiotów doświadcza negatywnych skutków już w okresie badania, a pozostałe będą doświadczać ich w ciągu miesiąca. Główne negatywne konsekwencje zaistniałej sytuacji to przewidywany brak środków na wynagrodzenia, brak środków na opłaty stałe, problemy z regulowaniem składek do Zakładu Ubezpieczeń Społecznych i zobowiązań podatkowych. Już w momencie badania $91 \%$ przedsiębiorstw wiedziało, że będzie miało problemy z regulowaniem swoich zobowiązań. Możliwość likwidacji przewidywało $27 \%$, a $46 \%$ jeszcze nie miało na ten temat zdania (por. Gajewski et al., 2020).

W okresie pandemii COVID-19 przedsiębiorstwa społeczne były beneficjentami instrumentów wprowadzonych ustawą z dnia 31 marca 2020 r. o zmianie ustawy o szczególnych rozwiązaniach związanych z zapobieganiem, przeciwdziałaniem i zwalczaniem COVID-19, innych chorób zakaźnych oraz wywołanych nimi sytuacji kryzysowych, a także niektórych innych ustaw, m.in. wskazanych art. 15zzb (podmioty wypełniające definicje przedsiębiorcy $\mathrm{z}$ ustawy Prawo przedsiębiorców) oraz art. 15zze (organizacje pozarządowe i podmioty, o których mowa w art. 3 ust. 3 ustawy z dnia 24 kwietnia 2003 r. o działalności pożytku publicznego i o wolontariacie). 
Narzędzia i instrumenty wsparcia, które były dostępne również dla PS i PES, to przede wszystkim:

- dofinansowania do wynagrodzenia ze środków Funduszu Gwarantowanych Świadczeń Pracowniczych w okresie wprowadzonego przez pracodawcę przestoju ekonomicznego lub obniżenia wymiaru czasu pracy,

- odroczenie terminu płatności lub rozłożenie na raty należności z tytułu składek należnych na ubezpieczenie społeczne,

- umorzenia składek na ubezpieczenie społeczne - zwolnienia z obowiązku opłacenia nieopłaconych należności z tytułu składek na ubezpieczenia społeczne, na ubezpieczenie zdrowotne, na Fundusz Pracy, Fundusz Solidarnościowy, Fundusz Gwarantowanych Świadczeń Pracowniczych lub Fundusz Emerytur Pomostowych, należnych za okres od dnia 1 marca 2020 r. do dnia 31 maja 2020 r.,

- dofinansowania wynagrodzeń oraz składek ze środków Funduszu Pracy dla przedsiębiorców,

- udzielanie niskooprocentowanych pożyczek dla mikroprzedsiębiorców ze środków Funduszu Pracy,

- niskooprocentowane pożyczki dla organizacji pozarządowych i podmiotów, o których mowa w art. 3 ust. 3 ustawy o działalności pożytku publicznego i o wolontariacie,

- dofinansowanie wynagrodzeń oraz składek ze środków Funduszu Pracy - dla organizacji pozarządowych i podmiotów, o których mowa w art. 3 ust. 3 ustawy o działalności pożytku publicznego i o wolontariacie,

- subwencja z Państwowego Funduszu Rehabilitacji Osób Niepełnosprawnych (PFRON),

- umorzenie/obniżenie czynszu za wynajem lokalu,

- wsparcie pomostowe/bony z OWES.

Wprowadzono też specjalne rozwiązania na rzecz ekonomii społecznej:

- mechanizm zakupowy (produkty/usługi na rzecz podmiotów potrzebujących w ramach przeciwdziałania COVID-19),

- w okresie trwania okresu epidemicznego i do upływu trzeciego miesiąca po jego zakończeniu wydłużoną do 12 miesięcy karencję w spłacie kapitału pożyczki płynnościowej (pożyczki ze środków Banku Gospodarstwa Krajowego) wraz z możliwością umorzenia do 25\% kapitału.

W odpowiedzi na lockdown, czyli ograniczenie możliwości prowadzenia działalności gospodarczej przez przedsiębiorstwa społeczne, podjęto działania mające za zadanie wspierać PS i PES w związku z przeciwdziałaniem negatywnym skutkom epidemii COVID-19. Dzięki współpracy środowiska tworzącego ekonomię społeczną podjęto konkretne działania: 
- badania mające prognozować wpływ COVID-19 na sektor ekonomii społecznej,

- wspólne apele środowisk ekonomii społecznej, Sieci Ośrodków Wsparcia Ekonomii Społecznej, Krajowego Komitetu Rozwoju Ekonomii Społecznej i Regionalnych Komitetów Rozwoju Ekonomii Społecznej,

- rekomendacje Ministra Funduszy i Polityki Regionalnej dot. wdrożenia w projektach OWES mechanizmu wsparcia PES i PS, poprzez przeprowadzanie przez OWES zakupów od tych podmiotów produktów lub usług związanych z przeciwdziałaniem skutkom wystąpienia COVID-19,

- uruchomienie możliwości wyłączenia zasady konkurencyjności podczas udzielania zamówień w projektach UE w związku z wystąpieniem siły wyższej (COVID-19). Specjalnym instrumentem wypracowanym $\mathrm{z}$ udziałem interesariuszy ekonomii społecznej był tzw. mechanizm zakupowy COVID-19 mający na celu przeciwdziałanie upadłości PS/PES i utrzymanie miejsc pracy zagrożonych w następstwie wystąpienia COVID-19. Zakupy miały na celu również wsparcie społeczności lokalnych w walce z COVID-19 i obejmowały m.in.:

- zamówienia produkowanych przez PES i PS materiałów ochrony osobistej (np. maseczek ochronnych) i przekazywanie ich nieodpłatnie placówkom służby zdrowia oraz placówkom całodobowej opieki,

- zamówienia usług cateringowych świadczonych przez PES i PS na potrzeby pracowników służby zdrowia,

- zamówienia usług cateringowych świadczonych przez PES i PS oraz przekazywanie ich nieodpłatnie osobom $\mathrm{w}$ trudnej sytuacji w związku $\mathrm{z}$ wystąpieniem COVID-19 (osobom starszym, osobom z niepełnosprawnościami i osobom potrzebującym wsparcia w codziennym funkcjonowaniu w społeczności lokalnej),

- zamówienia w PES i PS środków higienicznych (np. dezynfekujących) i przekazywanie ich nieodpłatnie placówkom służby zdrowia oraz placówkom całodobowej opieki.

Zakupy dokonywane były na podstawie procedury opracowanej we współpracy OWES z Regionalnymi Ośrodkami Polityki Społecznej zgodnie z Rekomendacjami Ministra Funduszy i Polityki Regionalnej (MFiPR) dot. wdrożenia w projektach OWES mechanizmu wsparcia PES i PS, poprzez przeprowadzanie przez OWES zakupów od tych podmiotów produktów lub usług związanych z przeciwdziałaniem skutkom wystąpienia COVID-19 (pismo MFiPR z 19 kwietnia 2020 r. (DZF-VI.7610.28.2020. ŁM) oraz rekomendacjami dotyczącymi koordynacji działań wspierających funkcjonowanie instytucji pomocowych i podmiotów ekonomii społecznej w związku z przeciwdziałaniem COVID-19. Departament Ekonomii Społecznej Ministerstwa Rodziny i Polityki Społecznej przeprowadził na koniec 2020 r. analizę działania mechanizmu zakupowego. Na podstawie 48 odpowiedzi (stan na 30.09.2021) wiadomo, że 
OWES wydały w ramach mechanizmu zakupowego łącznie kwotę 7857 819,06 PLN: najwięcej Wielkopolski Ośrodek Ekonomii Społecznej 1 124 769, 90 PLN (średnio 163 704,56 PLN). Najwięcej OWES wprowadziło mechanizm w maju 2020 r. (osiem podmiotów) i w czerwcu 2020 r. (także osiem podmiotów) i kolejne w następnych miesiącach. Niewątpliwie przyczyniło się to do złagodzenia trudnej sytuacji w przedsiębiorstwach społecznych, a jednocześnie realizowano też ważną funkcję dostarczenia niezbędnego wsparcia służbom medycznym i osobom potrzebującym.

\section{Koncepcja wsparcia dla ekonomii społecznej w perspektywie 2021-2027}

Koncepcja instrumentów finansowego ${ }^{3}$ wsparcia PES została przygotowana z wykorzystaniem wniosków z „Badania potrzeb finansowych i pozafinansowych w sektorze ekonomii społecznej oraz usług społecznych i zdrowotnych" (Gajewski et al., 2020) zrealizowanego na zlecenie Ministerstwa Funduszy i Polityki Regionalnej (MFiPR) Departamentu Europejskiego Funduszu Społecznego (DZF) na potrzeby programowania wsparcia dla PES w ramach perspektywy finansowej 2021-2027 (EFS+). Celem opracowania było przedstawienie planowanej kompleksowej oferty wsparcia finansowego, która w najbardziej adekwatny sposób zaspokoi potrzeby finansowe tych podmiotów, przy założeniu, że wsparcie w ramach dotacji oraz instrumentów zwrotnych będzie się uzupełniać, w celu optymalnego wykorzystania tych instrumentów zarówno do tworzenia nowych PES, jak i do systematycznej budowy potencjału PES już istniejących. Propozycja MFiPR odnosi się zatem wyłącznie do finansowego wsparcia PES (tj. nie obejmuje wsparcia pozafinansowego takiego jak np. zapotrzebowanie na usługi doradcze świadczone odrębnie od wsparcia finansowego). Założenia przedstawione przez MFiPR mają charakter wstępny, a zawartość dokumentu będzie podlegała aktualizacji w miarę postępu negocjacji umowy partnerstwa oraz programów operacyjnych, tak regionalnych jak i krajowego, jak również postępu prac nad projektem ustawy o ekonomii społecznej oraz aktualizacją Krajowego Programu Rozwoju Ekonomii Społecznej.

W przypadku katalogu instrumentów kierowanych do PES instrumenty bezzwrotne skierowane są wyłącznie do grupy podmiotów będących lub przekształcających się w PS. Dotychczasowe wsparcie dla przedsiębiorstw społecznych opierało się przede wszystkim na instrumentach dotacyjnych. Dotychczas było to niezbędne

3 Informacje zebrane przez autora podczas pracy w Krajowym Komitecie Rozwoju Ekonomii Społecznej w Grupie Finansowej. 
ze względu na potrzebę budowania sektora ekonomii społecznej wraz z grupami PS i PES. Dla PES nie ma dostępnej oferty kredytów bankowych. Głównym wyzwaniem tych podmiotów jest brak odpowiednich zabezpieczeń, co stanowi podstawową barierę w pozyskaniu finansowania zwrotnego. Większość PES nie dysponuje bowiem odpowiednimi aktywami ani możliwością pozyskania poręczeń. W przypadku podmiotów, które ubiegały się o kredyt, ale go nie otrzymały, na pierwszym miejscu jako powód odmowy wskazywano brak wymaganych zabezpieczeń, dalej zaś niską ocenę zdolności kredytowej potencjalnego kredytobiorcy, a wreszcie zbyt krótki czas prowadzenia działalności przez potencjalnego kredytobiorcę. W sytuacji wzmacniania się sektora i rozwoju przedsiębiorstw społecznych realną potrzebą jest udostępnienie dla PES instrumentów zwrotnych. Przedsiębiorstwa te w bliskiej perspektywie powinny funkcjonować $\mathrm{w}$ warunkach konkurencyjnej gospodarki rynkowej. Polityka UE zakłada stopniowe odchodzenie od dotacji na rzecz wsparcia zwrotnego. Badanie luki finansowej potwierdza skalę zapotrzebowania na finansowanie dłużne w wysokości co najmniej $60 \mathrm{mln}$ PLN rocznie (Andrzejewska et al., 2014: 62).

Innowacją w nowym okresie programowania będą nowe możliwości częściowego umorzenia kapitału dla pożyczek dotyczących finansowania przedsięwzięć ważnych z punktu widzenia polityki rozwoju. Jest to przede wszystkim realizacja usług społecznych świadczonych w społeczności lokalnej, usług zdrowotnych świadczonych w społeczności lokalnej lub obszarze zielonej gospodarki rozumianej jako podejmowanie działalności w obszarze termomodernizacji, zwiększania efektywności energetycznej, ekologicznej gospodarki odpadami, ochrony środowiska, edukacji w zakresie przeciwdziałania zanieczyszczeniu środowiska, ekoinnowacji, ekoturystyki, efektywnego gospodarowania wodą i zasobami. Stosunkowo duży potencjał do zwiększenia podaży tego typu usług w sektorze ekonomii społecznej został potwierdzony badaniem: $37 \%$ podmiotów, które nie świadczą tego typu usług, rozważało rozpoczęcie działalności w tym obszarze.

Ponadto zakłada się możliwość częściowego umorzenia pożyczki na rozwój w przypadku pożyczek udzielanych $\mathrm{z}$ równoczesnym utworzeniem - w ramach przedsięwzięcia finansowanego ze środków pożyczki - miejsc pracy dla osób z ograniczeniami sprawności lub osób z zaburzeniami psychicznymi. Wprowadzenie możliwości częściowego umorzenia pożyczki na rozwój stanowiłoby istotny czynnik motywujący pracodawcę do utrzymania takiego miejsca pracy. Proponowana wysokość umorzenia to 25\% kapitału pożyczki, pod warunkiem osiągnięcia zakładanych korzyści społecznych. Testowany w obecnym okresie programowania instrument social venture capital działający poprzez Fundusz Kapitałowych Inwestycji Społecznych będzie się dalej rozwijać, przeznaczając na finansowanie takiego instrumentu większą kwotę alokacji. Instrument jest skierowany do PS o znacznym potencjale 
wzrostu i pozwala im pozyskać finansowanie dla przedsięwzięć rozwojowych mających na celu wzmocnienie ich potencjału gospodarczego, pozycji na rynku oraz podniesienie ich konkurencyjności.

Warto zaznaczyć, że większość rozmówców podczas eksperckich badań jakościowych (Jóźko et al., 2018: 73) zauważa pewne zmiany o charakterze świadomościowym w sektorze ekonomii społecznej. Okazuje się bowiem, że podmioty ekonomii społecznej coraz częściej są zainteresowane korzystaniem ze zwrotnych instrumentów finansowych, co jest również związane z ich stopniowym upowszechnianiem w szeroko rozumianym systemie wsparcia. Zwiększa się poziom edukacji, liczba udzielanych pożyczek, ponadto coraz więcej podmiotów korzysta $\mathrm{z}$ więcej niż jednego instrumentu zwrotnego. $Z$ drugiej strony wciąż można mówić o znaczącej przewadze tradycyjnego modelu finansowania, opartego na dotacjach. Mając do wyboru różne sposoby finansowania, większość PES w pierwszej kolejności wybiera instrumenty bezzwrotne, co - zdaniem uczestników badania - jest najbardziej racjonalną strategią postępowania. Innymi słowy, instrumenty zwrotne wciąż mają znaczenie poboczne, uzupełniające względem modelu grantowego. Dodatkowym potwierdzeniem powyższej tezy jest fakt, że - jak wynika z wypowiedzi - podmioty ekonomii społecznej stanowią marginalną grupę klientów wielu funduszy pożyczkowych dla przedsiębiorców (np. w niewielkim stopniu korzystają z analizowanych w tym opracowaniu instrumentów działających na poziomie regionalnym). Wśród klientów korzystających ze zwrotnych instrumentów finansowych zdecydowanie przeważają organizacje pozarządowe (fundacje i stowarzyszenia), natomiast zdecydowanie rzadziej są to spółdzielnie socjalne, spółki z o.o. non-profit lub - w jednostkowych przypadkach - kościelne osoby prawne. Ograniczenia funkcjonowania związane z pandemią COVID-19 podsuwały czarny scenariusz podmiotom ekonomii społecznej. Szybka interwencja OWES, interesariuszy reprezentowanych w Krajowym Komitecie Rozwoju Ekonomii Społecznej oraz administracji rządowej i samorządowej pozwoliła wypracować praktyczny i efektywny mechanizm wsparcia, dzięki czemu zapobiegła znaczącej fali likwidacji i upadłości w sektorze. W sytuacji zagrożenia skutkami pandemii udało się zmobilizować środowisko zarówno instytucji wsparcia, podmiotów ekonomii społecznej, jak i decydentów do wspólnego wypracowania mechanizmów przeciwdziałania. W krótkim czasie podjęto dialog, rozpoznano sytuację poprzez zainicjowane oddolnie i przeprowadzone przez OWES badania, partnersko wypracowano i przyjęto zupełnie nowe rozwiązania wsparcia PS i PES (mechanizm zakupowy, karencje i umorzenia części kapitału pożyczek), wreszcie uzyskano zgodę na zmianę procedur i wdrożenie mechanizmu zakupowego, opierając się 
na doświadczeniu i wiedzy OWES. Pojawiły się konkretnie rozwiązania w zakresie instrumentów finansowych, które będą oddziaływały na decyzje dotyczące nowego okresu programowania. Obecnie ciągle jeszcze mamy do czynienia z ograniczeniami związanymi z pandemią COVID-19, trudno zatem jednoznacznie ocenić długofalowe efekty działań, ale badania dotyczące pierwszego etapu pandemii COVID-19 pokazują skuteczność interwencji i ograniczenie skutków kryzysu wśród podmiotów ekonomii społecznej.

\section{Źródło finansowania}

Artykuł powstał w związku z realizacją projektu pt. System partycypacyjnego zarzadzania sferą ekonomii społecznej. Działanie 2.9 Rozwój ekonomii społecznej PO WER (POWR.02.09.00-00-007/16).

\section{Bibliografia}

Alter, K.S. (2008). Typologia przedsiębiorstwa społecznego. W: Przedsiębiorstwo społeczne. Antologia tekstów kluczowych (143-168), J. Wygnański (red.). Warszawa: Fundacja Inicjatyw Społeczno-Ekonomicznych.

Andrzejewska, M., Ośka, M., Ponichter-Kolenda, M., Stronkowski, P., Zawistowski, J., Zych, M. (2014). Ocena ex-ante instrumentów finansowych $w$ zakresie wsparcia podmiotów ekonomii społecznej i osób młodych. Warszawa: Fundacja Naukowa Instytut Badań Strukturalnych i Coffey International Development Sp. z o.o.

Bilal, S., Krätke, F. (2013). Blending loans and grants for Development: An effective mix for the EU? ECDPM Briefing Note No. 55, October 2013, Maastricht.

Billis, D. (2010). Towards a theory of hybrid organizations. W: Hybrid Organizations and the Third Sector: Challenges for Practice, Theory and Policy (46-69), D. Billis (red.). New York: Palgrave Macmillan.

Gajewski M., Stronkowski P., Szczucki J. (2015). Ocena ex ante ryzyka dla zastosowania instrumentów finansowych o charakterze gwarancyjnym oferowanych podmiotom ekonomii spotecznej w ramach PO WER. Warszawa: Ministerstwo Infrastruktury i Rozwoju.

Gajewski, M., Kubajek, R., Pietrzak, B., Sochańska-Kawiecka, M., Szczucki, Witkowska, J., Bienias, J., Gapski, S., Kasoń, T., Kolczyński, S., Koniewski, M., Stronkowski, P., Trzciński, R. (2020). Badanie potrzeb finansowych i pozafinansowych w ekonomii społecznej oraz ustug społecznych i zdrowotnych. Warszawa: Ministerstwo Funduszy i Polityki Regionalnej.

Grabowska, I., Klimczak, T., Sołtan-Kościelecka, K., Miller, A., Wolińska, I. (2017). Raport końcowy do badania „ewaluacja systemu pożyczkowego". Warszawa: Ministerstwo Rodziny, Pracy i Polityki Społecznej.

Izdebski, H. (2006). Spółdzielnie socjalne a organizacje pozarządowe - przewidywane skutki Ustawy o spółdzielniach socjalnych. Trzeci Sektor, 7: 7-13. 
Izdebski, H. (2012). Anglosaski model ekonomii społecznej. W: Wokół ekonomii społecznej (89-95), M. Frączak, J. Hausner, S. Mazur (red.). Kraków: Małopolska Szkoła Administracji Publicznej, Uniwersytet Ekonomiczny w Krakowie.

Jóźko, M., Trochimiak-Jóźko, K., Chomicki, K. (2018). Raport dotyczacy podsumowania realizacji zwrotnych form finansowania podmiotów ekonomii społecznej i przedsiębiorstw społecznych wraz z rekomendacjami dla dalszej polityki publicznej w tym zakresie. Warszawa: Ministerstwo Pracy, Rodziny i Polityki Społecznej.

Kaźmierczak, T. (2013). Toward the social mission- based typology of social enterprises. EMES-SOCENT Conference Selected Papers.

Kaźmierczak, T. (2014). Reintegracja w sektorze ekonomii społecznej. Przedsiębiorstwa społeczne integracji przez pracę. W: Reintegracja. Aktywna polityka społeczna w praktyce (299-316), A. Karwacki, T. Kaźmierczak, M. Rymsza (red.). Warszawa: Fundacja Instytut Spraw Publicznych.

Kaźmierczak, T. (red.) (2008). W poszukiwaniu strategii pobudzania oddolnego rozwoju spoŁeczności wiejskich. Warszawa: Instytut Spraw Publicznych.

Kelly, S. (2003). Ekonomia społeczna i przedsiębiorczość społeczna w Unii Europejskiej. W: W stronę aktywnej polityki społecznej (35-36). T. Kaźmierczak, M. Rymsza (red.). Warszawa: Instytut Spraw Publicznych.

Lachowicz, T. (2008). Spółdzielczość socjalna w Polsce i we Włoszech. Analiza porównawcza wybranych elementów otoczenia prawno-społecznego. W: Gospodarka społeczna w Polsce. Możliwości, wybrane inicjatywy oraz szanse dalszego rozwoju, (79-93), A. Rymsza (red.). Warszawa: Fundacja Archidiecezji Warszawskiej Pomocy Bezrobotnym i Biednym Nadzieja.

Laville, J.-L., Nyssens, M. (2007). Przedsiębiorstwo społeczne. W stronę teoretycznego ujęcia socjoekonomicznego. W: Przedsiębiorstwo społeczne. Antologia tekstów kluczowych (311-332), J. Wygnański (red.). Warszawa: Fundacja Inicjatyw Społeczno-Ekonomicznych.

Leś, E., Ołdak, M. (red.) (2007). Przedsiębiorstwo społeczne w rozwoju lokalnym. Warszawa: Collegium Civitas Press.

Loss, M. (2005). Spółdzielnie socjalne we Włoszech. Trzeci Sektor, 45-58.

MGPiPS (Ministerstwo Gospodarki, Pracy i Polityki Społecznej) (2004). Program Inicjatywy Wspólnotowej EQUAL dla Polski. Warszawa: Ministerstwo Gospodarki, Pracy i Polityki Społecznej.

Monzón, J.L., Chaves, R. (2012). The Social Economy in the European Union. Brussels: European Economic and Social Committee.

MRiPS (Ministerstwo Rodziny i Polityki Społecznej) (2021). Wstępny projekt założeń ustawy o ekonomii społecznej i solidarnej. https://www.ekonomiaspoleczna.gov.pl/Wstepny,projekt,zalozen,do,ustawy,o,es,3990.html (dostęp: 30.10.2021)

MRPiPS (Ministerstwo Rodziny, Pracy i Polityki Społecznej) (2019). Krajowy Program Rozwoju Ekonomii Społecznej do roku 2023. Ekonomia Solidarności Społecznej. Monitor Polski, poz. 214, Warszawa.

MRR (Ministerstwo Rozwoju Regionalnego) (2007). Program Operacyjny Kapitał Ludzki. Narodowe Strategiczne Ramy Odniesienia 2007-2013. Warszawa: Ministerstwo Rozwoju Regionalnego. 
OECD (Organisation for Economic Co-operation and Development). Local Employment and Economic Development Programme (LEED) (2009). Improving social inclusion at the local level through the social economy. Report for Poland. Paris: OECD Publishing.

OWES (Ośrodki Wsparcia Ekonomii Społecznej) (2020). Przedsiębiorstwa społeczne a kryzys wywołany epidemia wirusa SARS-CoV-2 - badania ogólnopolskie. Poznań: Ośrodki Wsparcia Ekonomii Społecznej.

Pacut, A. (2012). Kontynentalny model ekonomii społecznej. W: Wokół ekonomii społecznej (73-88), M. Frączak, J. Hausner, S. Mazur (red.). Kraków: Małopolska Szkoła Administracji Publicznej, Uniwersytet Ekonomiczny w Krakowie.

Piechowski, A. (2007). Rodowód przedsiębiorczości społecznej. W: Przedsiębiorstwo społeczne w rozwoju lokalnym (45-53), E. Leś, M. Ołdak (red.). Collegium Civitas Press.

Rymsza, M. (2011a). Więziotwórcze funkcje przedsiębiorstw społecznych. Polityka Społeczna, 7: $14-18$.

Rymsza, M. (2011b). Wstęp. W: Polityka aktywizacji w Polsce: ustugi reintegracji $w$ sektorze gospodarki społecznej (3-10), M. Grewiński, M. Rymsza (red.). Warszawa: Wydawnictwo Wyższej Szkoły Pedagogicznej TWP.

Rymsza, M. (2014). Rola organizacji obywatelskich i sektora gospodarki społecznej w świadczeniu usług reintegracyjnych. W: Reintegracja: aktywna polityka społeczna w praktyce (359-382), A. Karwacki, T. Kaźmierczak, M. Rymsza. Warszawa: Fundacja Instytut Spraw Publicznych.

Sałustowicz, P. (2007). Pojęcie, koncepcje i funkcje ekonomii społecznej. W: Ekonomia społeczna. Perspektywa rynku pracy i pomocy społecznej (21-46), J. Staręga-Piasek (red.). Warszawa: Instytut Rozwoju Służb Społecznych.

Schimanek, T. (2012). Prawo przedsiębiorczości społecznej w 2011 roku. Trzeci Sektor, 27: 8-15.

Ustawa z dnia 24 kwietnia 2003 r. o działalności pożytku publicznego i o wolontariacie, Dz.U. $2003 \mathrm{Nr} 96$, poz. 873.

Ustawa z dnia 29 sierpnia 1997 r. Prawo bankowe, Dz. U. 2016, poz. 1988 z poźn. zm.

Ustawa z dnia 31 marca 2020 r. o zmianie ustawy o szczególnych rozwiązaniach związanych z zapobieganiem, przeciwdziałaniem i zwalczaniem COVID-19, innych chorób zakaźnych oraz wywołanych nimi sytuacji kryzysowych oraz niektórych innych ustaw, Dz.U. 2020, poz. 568.

Ustawa z dnia 6 marca 2018 r. Prawo przedsiębiorców, Dz.U. 2021, poz. 162.

Unless stated otherwise, all the materials are available under the Creative Commons Attribution 4.0 International license. Some rights reserved to SGH Warsaw School of Economics.

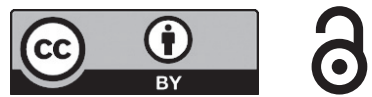

